\title{
DEVELOPING REGIONAL ENVIRONMENTAL MANAGEMENT MODELS IN COMPLIANCE WITH THE INNOVATIVE FORMAT OF ISO 14001:2015
}

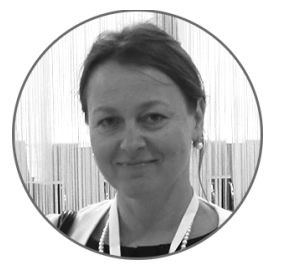

Svetlana V. RATNER

Trapeznikov Institute of Control Sciences of Russian Academy of Sciences, Moscow, Russian Federation

lanaratner@ipu.ru

Corresponding author

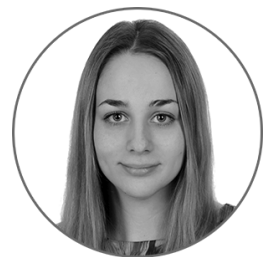

\section{Mariya D. RATNER}

Kuban State University, Krasnodar, Russian Federation

keep3up3@gmail.com

\section{Article history:}

Received 5 August 2016

Received in revised form 10 August 2016

Accepted 16 August 2016

Translated 25 May 2017

Available online 15 June 2017

JEL classification: Q51, Q58, R15

Keywords: environmental management, cluster analysis, regional socio-economic system, environmental effects

\begin{abstract}
Importance Considering the transition of environmental management systems to the innovative format under ISO 14001:2015, it necessitates models and methods for separate enterprises and organization to harmonize their natural protection strategies with strategies for developing regional social, environmental and economic systems, as a whole, and offers opportunities for improving local environmental management tools.

Objectives The research determines the types of regional economic systems in the constituent entities of the Russian Federation by volume and specifics of a negative environmental effect so to further optimize natural protection strategies at the regional level.

Methods The research relies upon a cluster analysis performed by the hierarchical clustering principle through the $k$-means method (clustering). Calculations were made using the Statistica software package, with the regions being clustered by a set of statistical indicators of the environmental cost of public interest product manufactured in a certain constituent entity of the Russian Federation, and indicators of households' consumption of natural resources and quality of environmental management in the housing and utilities sector. The information framework comprises State reports, On the Current Situation and Protection of Environment in the Russian Federation, for 2010 through 2014.

Results As the cluster analysis shows, it is possible to point out several types of regional socio-economic systems, where each of them can be linked with a certain model of regional environmental management, which would comply with the specifics of adverse effect the economy and population have on the environment. As for two principal models of regional environmental management, we proposed specific tools to encourage enterprises for more responsible environmentally-friendly behavior.

Conclusions and Relevance The proposed tools are market-oriented, stimulating the region's economy for adoption of the best available production technologies and subsequently supporting the region's economy and its economic development.
\end{abstract}

The editor-in-charge of this article was Irina M. Komarova

Authorized translation by Irina M. Komarova 
ISO 14001 Environmental Management has been implemented for twenty years globally at enterprises and organizations operating in various sectors, proving its high efficiency as a tool for raising the environmental responsibility of companies. According to multiple empirical studies, most enterprises certified under ISO 14001 reduce their adverse impact on the environment within several years after they adopt the environmental management system. It helps them cut their environmental charges, improve their corporate image for customers and partners and elevate the quality of general management [1, 2].

Starting from the first version of the standard developed in 1996 under the Deming cycle, flexible requirements to the environmental management system remain the principle driver of its success. This flexibility helps any company set up its own environmental management system in line with its internal specifics, i.e. sector, governance, technological level, etc., identify robust approaches to improving environmental indicators of its performance. Although it allows companies to focus on their own interests, the standard fails to provide solutions to specific needs of regional environmental management as compared with the EMAS (EU Eco-Management and Audit Scheme). It obliges enterprises to satisfy rather stringent environmental requirements of third parties.

In 2015, ISO 14001 was revised and brought into compliance with the ISO innovative format to develop management standards [3]. If compared with the 2007 version that is currently effective in Russia, the 2015 version includes such concepts as interested parties and the context of the organization. Thus, the new version of the standard treats the enterprise as an agent of a certain social, environmental and economic system, rather than an isolated agent. As per the new version, the agent should consider cumulative consequences that may arise for the region's environment from economic activities of each agent within the system [4].

The Russian standard is expected to be approved soon in accordance with the new version of ISO 14001:2015, and entities are supposed to adopt it within three years. Hence, it becomes especially important to address and consider the issues relating to the development of methods and tools for assessing cumulative environmental effects of regional socio-economic systems and harmonizing natural protection strategies of enterprises at the regional level.

The research pursues determining the types of regional economic systems in the constituent entities of the Russian Federation by extent and specifics of adverse effects they have on further optimization of natural protection strategies at the regional level. The information framework relies upon annual governmental reports, On the Situation and Protection of Environment in the Russian Federation, for 2010-2014'. The research mainly relies upon a cluster analysis performed by the hierarchical clustering principle through the $k$-means method. As its important advantage in comparison with other clustering algorithms, the $k$-means method helps researchers directly quantify clusters in accordance with theoretical considerations and objectives of the research [5]. Following the context of this research, as many clusters can be selected as needed to implement variable regional environmental policies. Calculations under the method were made using the Statistica software application.

Conducting the cluster analysis, we applied such statistical indicators that reflect the environmental cost of the public interest product manufactured in the constituent entity of the Russian Federation:

1) intensity of pollutant emissions from stationary sources per unit of gross regional product (GRP);

2) intensity of pollutant emissions from motor vehicles per GRP unit;

3) intensity of contaminated wastewater discharge per GRP unit;

4) intensity of insufficiently purified wastewater discharge per GRP unit;

5) intensity of waste generation per GRP unit;

6) intensity of water consumption (volume of fresh water intake from all natural sources) per GRP unit.

Furthermore, we used some statistical indicators describing the intensity of domestic consumption of natural resources by the regional population, and the quality of environmental management in the housing and utilities sector:

\section{1) emissions of motor vehicles per capita;}

\footnotetext{
${ }^{1}$ Governmental Reports, On the Situation and Protection of Environment in the Russian Federation, for 2009-2014. Available at: http://www.mnr.gov.ru/regulatory/list.php?part=1101 (In Russ.)
} 
2) volume of contaminated wastewater discharge per capita;

3) volume of insufficiently purified wastewater discharge per capita;

4) volume of solid domestic waste per capita;

5) intensity of water consumption (volume of fresh water intake from all natural sources) per capita.

All the statistical indicators were aligned with comparable measurement scale so to ensure the consistency of environmental effects and subsequently group (cluster) the regions. We used average values of each indicator for the period under study (2010-2014) so to ensure the clustering reliability and avoid that the type of the regional economic system may be erroneously identified due to natural force majeure or anthropogenic phenomena.

As the ANOVA test shows within the clustering process, all the indicators appear to be significant (at the statistical significance threshold where $p$ exceeds 0.05 ) to split the regions into five clusters, excluding the intensity of insufficiently purified wastewater per GRP unit and volume of emissions from motor vehicles. Analyzing the chart of average indicators (Fig. 1), it is easy to notice that agents of the third cluster mainly differ from the other regional environmental system due to their extremely high water consumption (higher rate per GRP unit, and lower rate per capita).

High water consumption is the most important feature of the fourth cluster, though it is more moderate than that one in the third cluster. The second cluster demonstrates the intensive discharge of contaminated wastewater per capita. The first cluster also intensively discharges contaminated wastewater per capita, however this adverse environmental effect is still not so strong as that one in the second cluster. The fifth cluster has the lowest weighted environmental impact as compared with the other clusters in terms of each indicator under study.

Tab. 1 shows how the regions are clustered ${ }^{2}$.

When the regions are split into four clusters, the following indicators proved to be statistically insignificant (statistical significance $p>0.05$ ):

\footnotetext{
${ }^{2}$ Calculations exclude Moscow and Saint Petersburg since they are separate constituent entities of the Russian Federation, having incomparable environmental indicators as compared with other regions and being able to substantially misstate the results of the model. Furthermore, the Republic of Crimea and the City of Sevastopol are also out of the assessment, with their figures being collected for 2014 only.
}

1) intensity of emissions from stationary sources per GRP unit ( $p=0.14)$;

2) intensity of insufficiently purified wastewater discharge per GRP unit ( $p=0.29$ );

3) intensity of emissions from motor vehicles per capita $(p=0.64)$;

4) intensity of insufficiently purified wastewater discharge per capita $(p=0.39)$.

Drawing upon the result of the $k$-means analysis of indicators per cluster (Fig. 2), we can point out the following differences among regions in different clusters:

- regions of the first cluster have the highest intensity of contaminated wastewater discharge per capita and increased water consumption per GRP unit;

- regions of the second cluster have the highest water consumption per GRP unit and per capita;

- regions of the third cluster demonstrate moderate and balanced adverse effect on the environment (without clear negative environmental effects);

- regions of the fourth cluster have rather high water consumption per GRP unit and per capita, but still less than regions of the second cluster do.

Analyzing how the regions are clustered (Tab. 2), it is easy to see that the four-cluster division eliminates the difference between the most representative groups of regions with a moderate environmental footprint and regions with higher intensity of contaminated wastewater discharge per capita, as opposed to the five-cluster approach.

No changes take place in groups of regions with extremely high water consumption (Cluster 3 if split into five groups and Cluster 2 if split into four groups), high water consumption (Cluster 4) and intensive discharge of contaminated wastewater per capita (Cluster 2 if split into five groups and Cluster 1 if split into four groups).

When the regions are clustered into three groups, the intensity of water consumption per GRP unit and per capita and the intensity of wastewater discharge per capita become the most specific distinction (Fig. 3). However, being the result of the division into four groups, Clusters 3 and 4 are merged.

Therefore, as the experiment with the number of clusters shows, several specific types of regional 
systems can be identified through statistical indicators that reflect the intensity of adverse environmental effects that socio-economic activities of people have (Fig. 4):

- socio-economic system where the economy and the housing and utilities sector have critically high water consumption (Type 1);

- regional socio-economic system where the housing and utilities sector has very intensive discharge of contaminated wastewater (Type 2);

- regional socio-economic system where the economy and housing and utilities sector have moderate and balanced adverse effect on the environmental system of the region (Type 3).

Furthermore, Type 3 can be split into several subtypes, which are not so explicit, but still different from each other:

- regional socio-economic system with high water consumption (Subtype 3.1);

- regional socio-economic system where the housing and utilities sector intensively discharges contaminated wastewater (Subtype 3.2);

- regional socio-economic system with the minimum level of specific adverse effect on the environment (Subtype 3.3).

Type 3 can be further divided into subtypes depending on the nature of prevailing adverse environmental effects. The extent of such divisions depends on the required number of clusters and practical purposes.

The proposed typology can be utilized to devise regional environmental management models that would be consistent with the specifics of adverse effect the region's economy and population have on the environment. Attributable to Type 1 of the regional socio-economic system, Regional Environmental Management Model 1 should, first of all, imply a set of stimulating and restricting administrative and market measures, which would incentivize the region's enterprises and organizations for reasonable water consumption, including those operating in the housing and utilities sector. As part of the second type of the regional socio-economic system, Regional Environmental Management Model 2 should foster new technologies of wastewater purification to be implemented, retrofitting of the existing wastewater treatment facilities and construction of new ones. Environmental Management Models within Subtypes 3.1 and 3.2 of the regional socio-economic system can be identical to Models 1 and 2 in terms of the nature of their environmental impact, but differ due their stringent regulations and requirements, intensity of incentives and disincentives.

Having analyzed the way environmental management systems were practically implemented worldwide, we highlighted the following popular mechanisms to boost environmental responsibility of entities and organizations, including the regional level:

- requirements to monitor a certain set of environmental indicators (considering the most vital issues of the region) of corporate performance, and report those indicators to special certification authorities or putting them into public domain $[6,7]$;

- development of the best available technologies for reducing the environmental footprint of enterprises operating in various sectors, and putting the respective information into the public domain $[8,9,10]$;

- support to investment programs and projects enterprises undertaking to adopt the best-in-class available technologies [11, 12, 13];

- creation of platforms, including electronic ones, for sharing the experience in implementation of the best available technologies in the economy and the housing and utilities sector $[14,15,16]$.

We assume, Regional Environmental Management Models 1 and 2 can include all the above popular and proven tools for incentivizing higher environmental responsibility of companies. Those tools can differ by their focus on water consumption reduction (Model 1) or decrease in the waster water discharge in the housing and utilities sector (Model 1, Tab. 3).

It is worth mentioning that the proposed incentives are market-oriented, rather than being administrative and pursuing the environmental responsibility of businesses and population. Adhering to this approach, the proposed measures will yield the desired effect over some time, however it will be productive and effective in the long run, according to researches referred [17, 18], other than using restrictions only, such as environmental charges and penalties. 
The proposed approach to setting up the regional environmental management system has another important distinction from the existing technologies for regulation of enterprises' adverse environmental footprint. It does not consider that environmental systems are able to cushion adverse effects and recover themselves, while various rates and standards of tolerable effects are assessed and based on such a crucial criterion as the ability of the environmental system to recycle wastes and emissions without a critical detriment to its quality ${ }^{3}$. Such criteria can generally change over time ${ }^{4}$, without pushing the economy towards the best available technologies of production, which are mostly science-intensive and innovative. It affects not only the environment, but also the economic development.

The proposed approach can be further elaborated by specifying types of regional socio-economic systems and, respectively, finding new regional environmental management models, and by optimizing the intensity of managerial involvement into lowering some adverse environmental footprints so to achieve the best environmental indicators as much as possible. Assuming that the first scenario be feasible using the clustering method, the second one requires more complex mathematical methods to be used, such as non-parametric optimization $[19,20]$ and its various modification [21, 22].

\footnotetext{
${ }^{3}$ Ratner S.V., Almastyan N.A. [Market and public methods to manage the environmental impact of electricity generation facilities].

Ekonomicheskii analiz: teoriya i praktika = Economic Analysis: Theory and Practice, 2015, no. 16, pp. 2-15. (In Russ.)

${ }^{4}$ For example, in 2014, tolerable concentration of formaldehyde substantially rose (more than three times as high as the earlier accepted rates). It had a drastic effect on the environmental situation in 33 percent of Russian cities (Governmental Reports, On the Situation and Protection of the Environment in the Russian Federation, in 2014). Available at: http://www.mnr.gov.ru/regulatory/list.php?part=1101 (In Russ.)
}

Please cite this article as: Ratner S.V., Ratner M.D. Developing Regional Environmental Management Models in Compliance with the Innovative Format of ISO 14001:2015. Digest Finance, 2017, vol. 22, iss. 2, pp. 163-174. 


\section{Table 1}

Distribution of regions by group as part of the five-cluster approach

\begin{tabular}{lll}
\hline Cluster & $\begin{array}{l}\text { The number } \\
\text { of regions }\end{array}$ & Constituent entity of the Russian Federation \\
\hline 18 & 18 & $\begin{array}{l}\text { Arkhangelsk Oblast, Vologda Oblast, Kaliningrad Oblast, Leningrad Oblast, Novgorod Oblast, } \\
\text { Republic of Kalmykiya, Republic of Tatarstan, Udmurt Republic, Perm Krai, Kirov Oblast, Sverdlovsk } \\
\text { Oblast, Chelyabinsk Oblast, Zabaykalsky Krai, Krasnoyarsk Krai, Irkutsk Oblast, Khabarovsk Krai, } \\
\text { Magadan Oblast, Sakhalin Oblast }\end{array}$ \\
\hline 2 & $\begin{array}{l}\text { Republic of Karelia, Murmansk Oblast, Krasnodar Krai, Kemerovo Oblast, Kamchatka Krai, Primorsky Krai, } \\
\text { Chukotka Autonomous Okrug }\end{array}$ \\
\hline 3 & Karachay-Cherkess Republic \\
\hline 5 & Kostroma Oblast, Tver Oblast, Republic of Dagestan, Kabardino-Balkar Republic, \\
& Republic of North Ossetia - Alania \\
\hline 4 & $\begin{array}{l}\text { Belgorod Oblast, Bryansk Oblast, Vladimir Oblast, Voronezh Oblast, Ivanovo Oblast, Kaluga Oblast, Kursk } \\
\text { Oblast, Lipetsk Oblast, Moscow Oblast, Orel Oblast, Pskov Oblast, Ryazan Oblast, Smolensk Oblast, } \\
\text { Tambov Oblast, Tula Oblast, Yaroslavl Oblast, Komi Republic, Republic of Adygea, Astrakhan Oblast, } \\
\end{array}$ & $\begin{array}{l}\text { Volgograd Oblast, Rostov-on-Don Oblast, Republic of Ingushetia, Chechen Republic, Stavropol Krai, } \\
\text { Republic of Bashkortostan, Mari El Republic, Republic of Mordovia, Chuvash Republic, Nizhny Novgorod } \\
\text { Oblast, Orenburg Oblast, Penza Oblast, Samara Oblast, Saratov Oblast, Ulyanovsk Oblast, Kurgan Oblast, } \\
\end{array}$ \\
& $\begin{array}{l}\text { Tyumen Oblast, Altai Republic, Republic of Buryatia, Tyva Republic, Republic of Khakassia, Altai Krai, } \\
\text { Novosibirsk Oblast, Omsk Oblast, Tomsk Oblast, Sakha Republic (Yakutia), Amur Oblast, Jewish } \\
\text { Autonomous Oblast }\end{array}$ \\
\hline
\end{tabular}

Source:Authoring

Table 2

Grouping of regions as part of the four-cluster approach

\begin{tabular}{lll}
\hline Cluster & $\begin{array}{l}\text { The number of } \\
\text { constituent entities }\end{array}$ & Constituent entity of the Russian Federation \\
\hline 1 & 7 & $\begin{array}{l}\text { Karelia Republic, Murmansk Oblast, Krasnodar Krai, Kemerovo Oblast, Kamchatka Krai, Primorky Krai, } \\
\text { Chukotka Autonomous Okrug }\end{array}$ \\
\hline 2 & Karachay-Cherkess Republic \\
\hline 3 & Arkhangelsk Oblast, Vologda Oblast, Kaliningrad Oblast, Leningrad Oblast, Novgorod Oblast, \\
& Republic of Kalmykia, Republic of Tatarstan, Udmurt Republic, Perm Krai, Kirov Oblast, \\
& Sverdlovsk Oblast, Chelyabinsk Oblast, Zabaykalsky Krai, Kransoyarsk Krai, Irkutsk Oblast, \\
& Khabarovsk Krai, Magadan Oblast, Sakhalin Oblast, Belgorod Oblast, Bryansk Oblast, Vladimir Oblast, \\
& Voronezh Oblast, Ivanovo Oblast, Kaluga Oblast, Kursk Oblast, Lipetsk Oblast, Moscow Oblast, \\
& Orel Oblast, Ryazan Oblast, Smolensk Oblast, Tambov Oblast, Tula Oblast, Yaroslavl Oblast, Pskov Oblast, \\
& Komi Republic, Republic of Adygea, Astrakhan Oblast, Volgograd Oblast, \\
& Rostov-on-Don Oblast, Republic of Ingushetia, Chechen Republic, Stavropol Krai, \\
& Republic of Bashkortostan, Mari El Republic, Republic of Mordovia, Chuvash Republic, Nizhny Novgorod \\
& Oblast, Orenburg Oblast, Penza Oblast, Samara Oblast, Saratov Oblast, Ulyanovsk Oblast, Kurgan Oblast, \\
& Tyumen Oblast, Altai Republic, Republic of Buryatia, Tyva Republic, Republic of Khakassia, Altai Krai, \\
& Novosibirsk Oblast, Omsk Oblast, Tomsk Oblast, Sakha Republic (Yakutia), Amur Oblast, Jewish \\
& Autonomous Oblast \\
\hline & Kostroma Oblast, Tver Oblast, Republic of Dagestan, Kabardino-Balkar Republic, Republic of North \\
& Ossetia - Alania \\
\hline
\end{tabular}

Source:Authoring 


\section{Table 3}

A list of tools stimulating regional environmental management systems

\begin{tabular}{|c|c|c|}
\hline Tool & Model 1 & Model 2 \\
\hline Monitoring & $\begin{array}{l}\text { 1. Requirements to monitor how much water is consumed } \\
\text { by enterprises and organization, including those operating } \\
\text { in the housing and utilities sector (volume of fresh water } \\
\text { intake from all sources, calculation of water trail of various } \\
\text { products, percentage of recycling and recirculating water). } \\
\text { 2. Requirements to publicly release (on specialized websites) } \\
\text { information on monitoring results }\end{array}$ & $\begin{array}{l}\text { 1. Requirements to monitor the generation and purification } \\
\text { level of wastewater in the housing and utilities sector } \\
\text { (volume of sewage, percentage of purified, insufficiently } \\
\text { purified and non-purified wastewater). } \\
\text { 2. Requirements to publicly release (on specialized websites) } \\
\text { information on monitoring results, and technologies used } \\
\text { to purify water and their compliance with global standards }\end{array}$ \\
\hline Technology & $\begin{array}{l}\text { 1. Developing (or adapting the existing federal and sectoral } \\
\text { technologies) the list of best-in-class available } \\
\text { technologies for water consumption reduction in various } \\
\text { types of production and housing and utilities sector }\end{array}$ & $\begin{array}{l}\text { 1. Developing (or adapting the existing federal and sectoral } \\
\text { technologies) the list of best-in-class available } \\
\text { technologies for domestic wastewater purification }\end{array}$ \\
\hline Taxes, benefits & $\begin{array}{l}\text { 1. Developing tax incentives for enterprises and } \\
\text { organizations, including the housing and utilities sector, } \\
\text { to adopt the best available technologies more quickly } \\
\text { for lowering water consumption. } \\
\text { 2. Preferential lending for projects of enterprises and } \\
\text { organization's adoption of the best available technologies } \\
\text { for cutting water consumption (including the housing and } \\
\text { utilities sector). } \\
\text { 3. Water consumption tariff regulation }\end{array}$ & $\begin{array}{l}\text { 1. Developing tax incentives for housing and utilities } \\
\text { enterprises to adopt the best available technologies more } \\
\text { quickly for improving the wastewater purification. } \\
\text { 2. Preferential lending for projects of housing and utilities } \\
\text { enterprises to adopt the best available technologies for } \\
\text { improved purification of wastewater. } \\
\text { 3. Developing the regional market for wastewater } \\
\text { purification equipment designated for private houses, } \\
\text { including the regulation of regional coefficient for trading } \\
\text { enterprises subject to imputed income tax treatment }\end{array}$ \\
\hline Information & $\begin{array}{l}\text { 1. Information campaigns for spreading the best available } \\
\text { technologies for reduction in domestic water consumption. } \\
\text { 2. Regional forums and conferences for commercial } \\
\text { implementation of the best available water consumption } \\
\text { technologies }\end{array}$ & $\begin{array}{l}\text { 1. Information campaigns for spreading the best available } \\
\text { technologies for wastewater purification for private use }\end{array}$ \\
\hline
\end{tabular}

Source:Authoring

Please cite this article as: Ratner S.V., Ratner M.D. Developing Regional Environmental Management Models in Compliance with the Innovative Format of ISO 14001:2015. Digest Finance, 2017, vol. 22, iss. 2, pp. 163-174. 


\section{Figure 1}

Chart of averages as part of the five-cluster approach

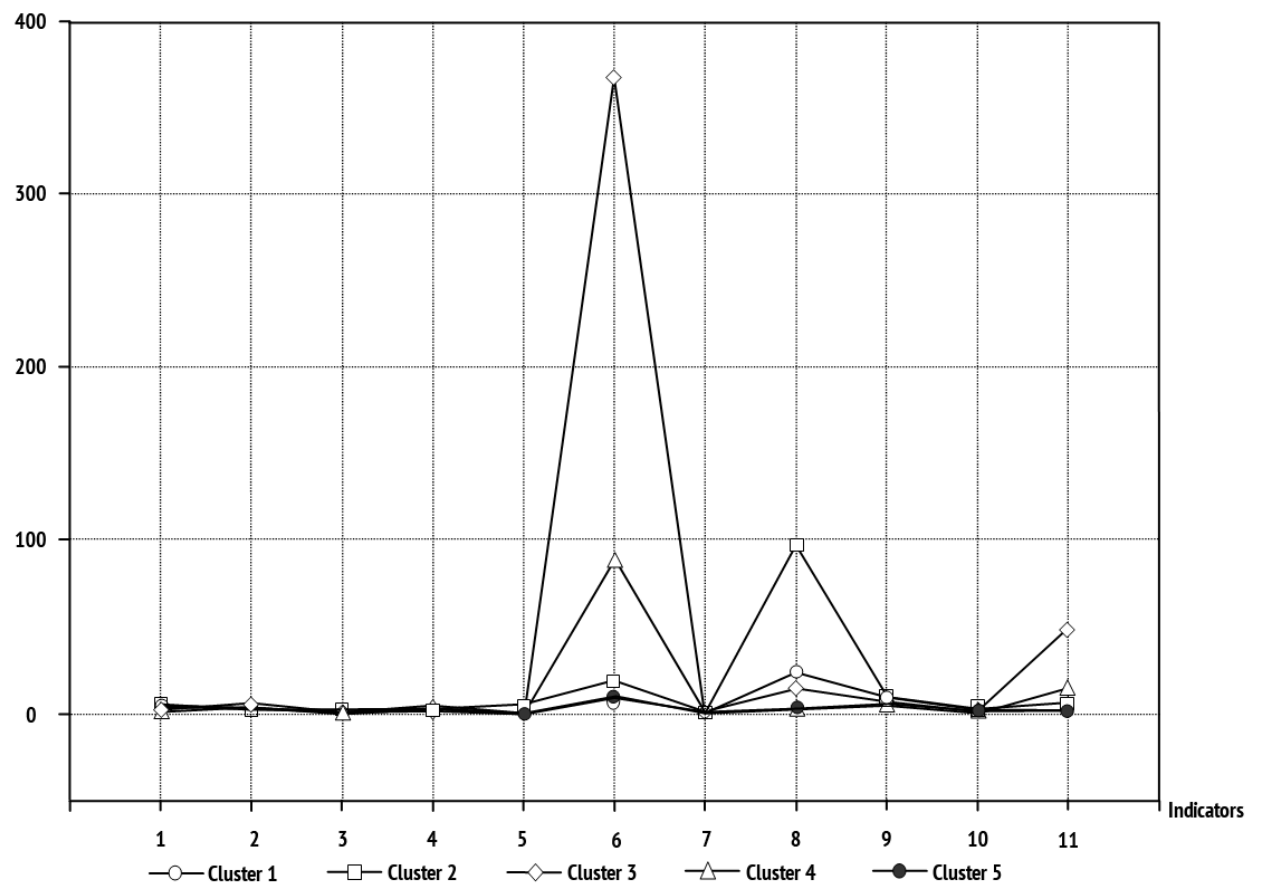

Note. 1 - the intensity of pollutant emissions from stationary sources per GRP unit; 2 - the intensity of pollutant emissions from motor vehicles per GRP unit; 3 - the intensity of contaminated wastewater discharge per GRP unit; 4 - the intensity of insufficiently purified wastewater discharge per GRP unit; 5 - the waste intensity per GRP unit; 6 - the water consumption intensity (volume of fresh water intake from all natural sources) per GRP unit; 7 - the emission from motor vehicles per capita; 8 - volume of contaminated wastewater discharge per capita; 9 - volume of insufficiently purified wastewater discharge per capita; 10 - volume of solid domestic waste per capita; 11 - the water consumption intensity (volume of fresh water intake from all natural sources) per capita.

\section{Source:Authoring}




\section{Figure 2}

Chart of averages as part of the four-cluster approach

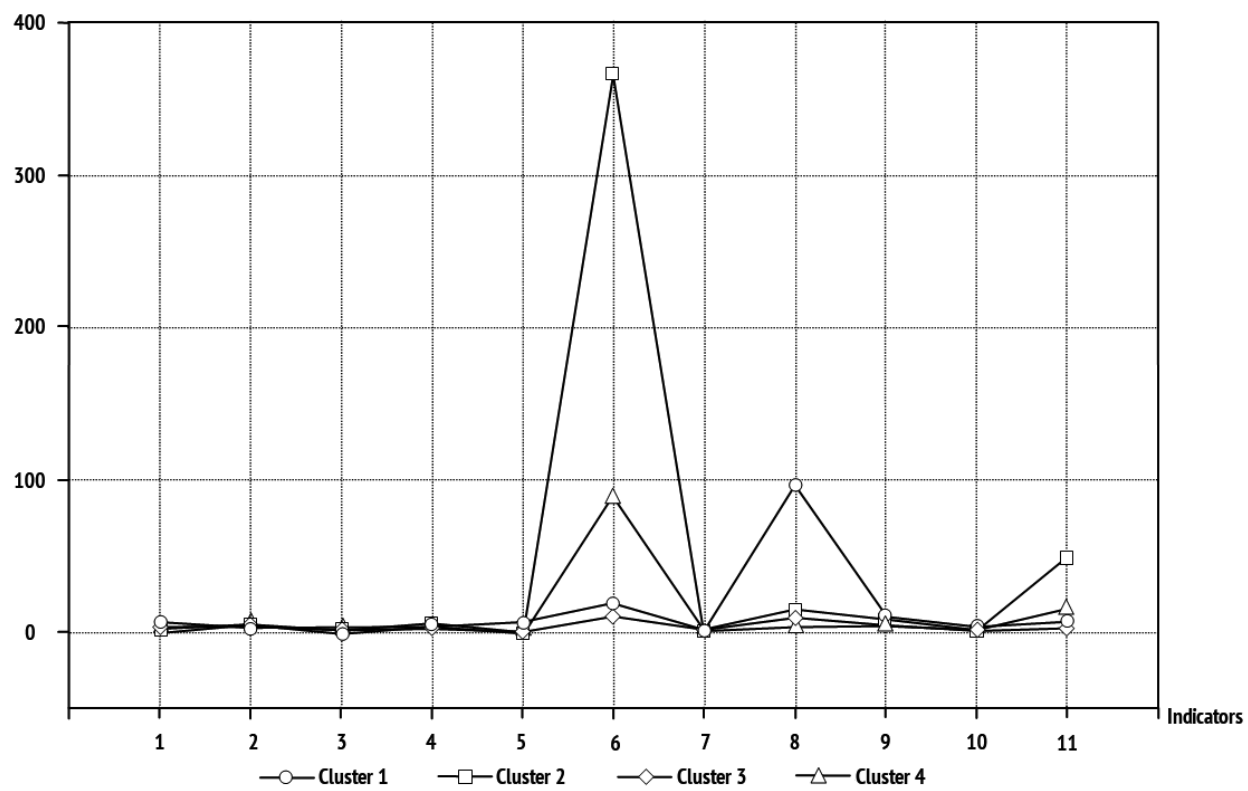

Note. 1 - the intensity of pollutant emissions from stationary sources per GRP unit; 2 - the intensity of pollutant emissions from motor vehicles per GRP unit; 3 - the intensity of contaminated wastewater discharge per GRP unit; 4 - the intensity of insufficiently purified wastewater discharge per GRP unit; 5 - the waste intensity per GRP unit; 6 - the water consumption intensity (volume of fresh water intake from all natural sources) per GRP unit; 7 - the emission from motor vehicles per capita; 8 - volume of contaminated wastewater discharge per capita; 9 - volume of insufficiently purified wastewater discharge per capita; 10 - volume of solid domestic waste per capita; 11 - the water consumption intensity (volume of fresh water intake from all natural sources) per capita.

Source: Authoring 


\section{Figure 3}

Chart of averages as part of the three-cluster approach

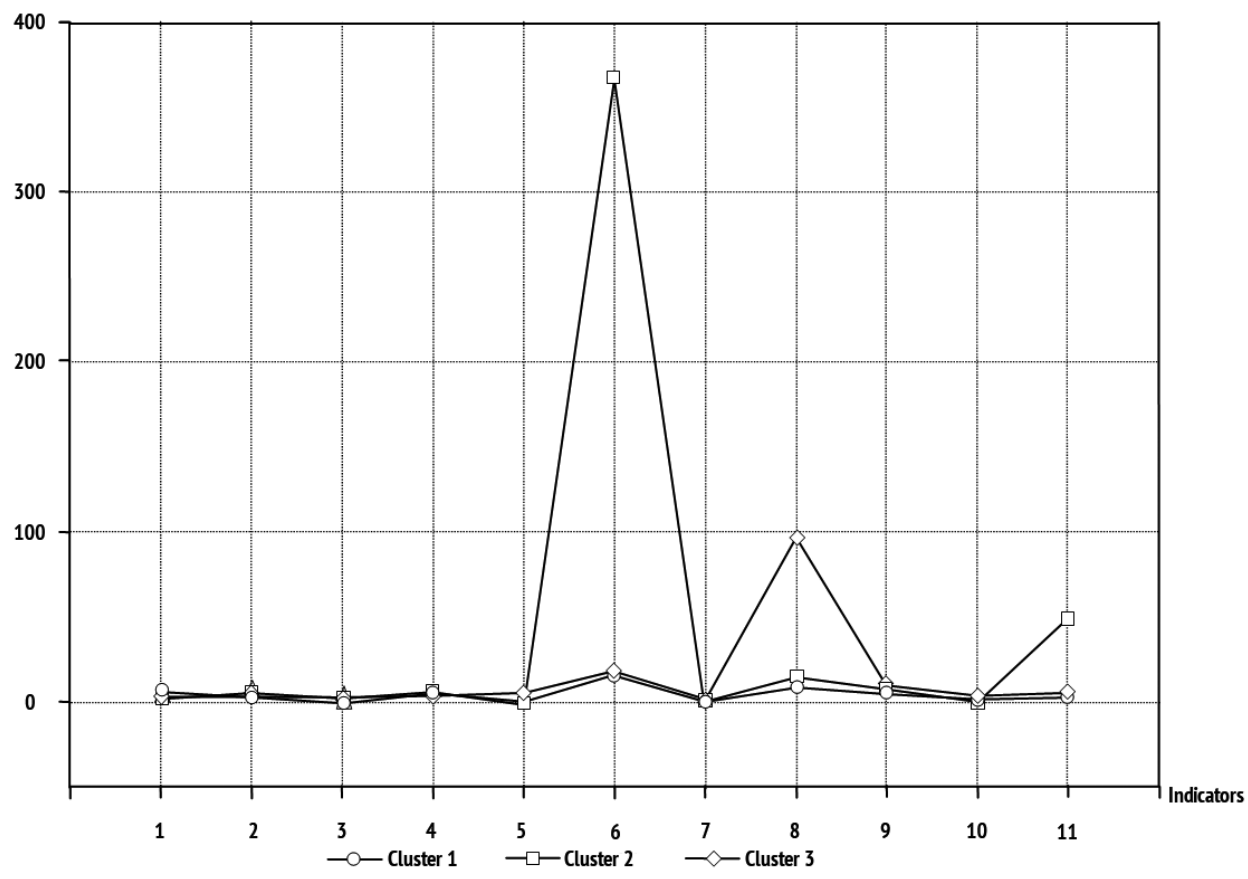

Note. 1 - the intensity of pollutant emissions from stationary sources per GRP unit; 2 - the intensity of pollutant emissions from motor vehicles per GRP unit; 3 - the intensity of contaminated wastewater discharge per GRP unit; 4 - the intensity of insufficiently purified wastewater discharge per GRP unit; 5 - the waste intensity per GRP unit; 6 - the water consumption intensity (volume of fresh water intake from all natural sources) per GRP unit; 7 - the emission from motor vehicles per capita; 8 - volume of contaminated wastewater discharge per capita; 9 - volume of insufficiently purified wastewater discharge per capita; 10 - volume of solid domestic waste per capita; 11 - the water consumption intensity (volume of fresh water intake from all natural sources) per capita.

\section{Source:Authoring}




\section{Figure 4}

Types of regional economic systems by intensity of their negative environmental footprint

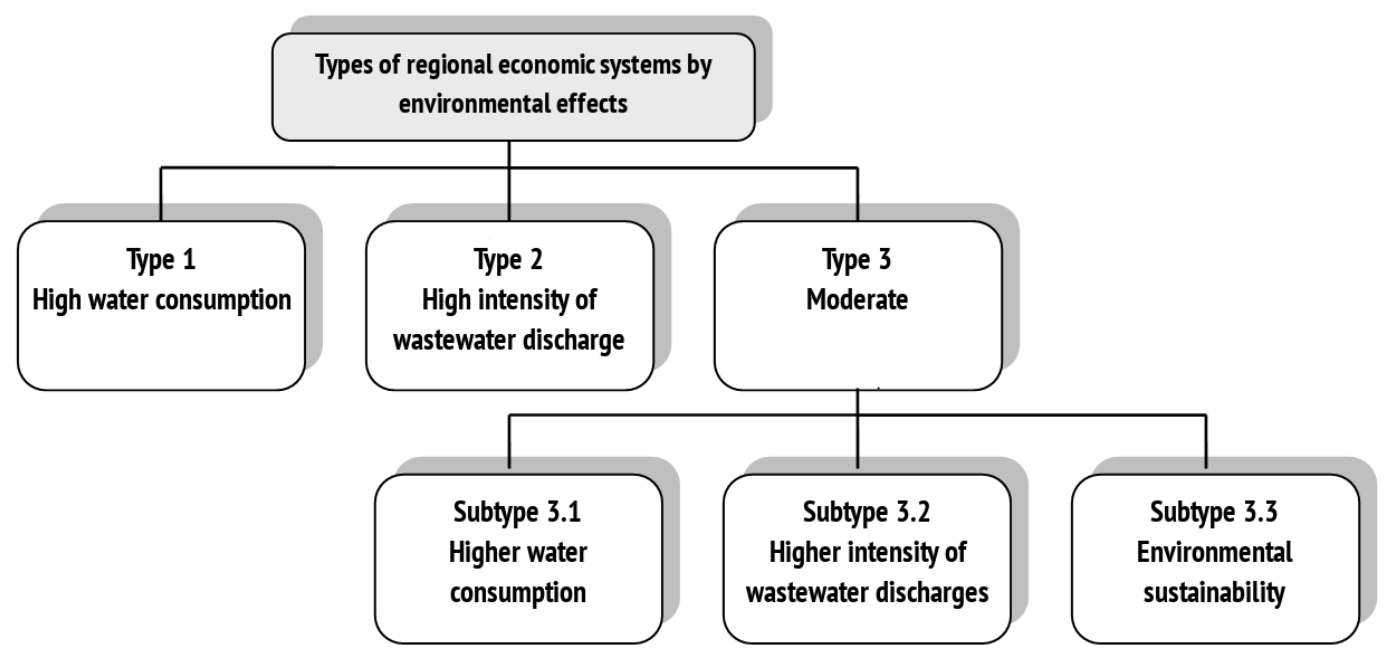

Source. Authoring

\section{Acknowledgments}

The research was supported by the Russian Foundation for Basic Research, project No. 16-06-00147, Setting Up Operational Environment Analysis Models to Optimize Development Paths of Regional Economic Systems from Environmental Perspectives.

\section{References}

1. Molina-Azorín J.F., Tarí J.J., Claver-Cortés E., López-Gamero M.D. Quality Management, Environmental Management and Firm Performance: A Review of Empirical Studies and Issues of Integration. International Journal of Management Reviews, 2009, vol. 11, iss. 2, pp. 197-222. doi: https://doi.org/10.1111/j.1468-2370.2008.00238.x

2. Franchetti M. ISO 14001 and Solid Waste Generation Rates in US Manufacturing Organizations: An Analysis of Relationship. Journal of Cleaner Production, 2011, vol. 19, iss. 9-10, pp. 1104-1109. doi: https://doi.org/10.1016/j.jclepro.2011.01.004

3. Belobragin V.Ya. [Rubicon. Analysis report, The ISO Survey-2014]. Standarty $i$ kachestvo = Standards and Quality, 2016, no. 1, pp. 90-96. (In Russ.)

4. Almastyan N.A. [Environmental management system: ISO 14001:2015 and EMAS]. Upravlenie kachestvom: materialy Mezhdunarodnoi nauchno-prakticheskoi konferentsii [Proc. 15th Int. Sci. Conf. Quality Management, March 10-11, 2016]. Moscow, PROBEL-2000, MAI Publ., 2016, 384 p.

5. Cameron A.C., Trivedi P.K. Mikroekonometrika: metody i ikh primenenie [Microeconometrics: Methods and Applications]. Moscow, Delo Publ., 2015, 664 p.

6. Testa F., Rizzi F., Daddi T., Gusmerotti N.M., Frey M., Iraldo F. EMAS and ISO 14001: The Differences in Effectively Improving Environmental Performance. Journal of Cleaner Production, 2014, vol. 68, pp. $165-173$. doi: https://doi.org/10.1016/j.jclepro.2013.12.061

7. Comoglio C., Botta S. The Use of Indicators and the Role of Environmental Management Systems for Environmental Performances Improvement: A Survey on ISO 14001 Certified Companies in the Automotive Sector. Journal of Cleaner Production, 2012, vol. 20, iss. 1, pp. 92-102. doi: 10.1016/j.jclepro.2011.08.022 
8. Berezyuk M.V., Rumyantseva A.V., Merzlikina Yu.B., Makarova D.N. [The choice of the best available technologies: economic aspects]. Vestnik UrFU. Ser. Ekonomika i upravlenie = Vestnik of Ural Federal University. Series: Economics and Management, 2014, no. 2, pp. 109-121. (In Russ.)

9. Skobelev D.O., Mezentseva O.V. [BAT-control and prevent negative impacts on our environment]. Kontrol' kachestva produktsii = Quality Control, 2014, no. 6, pp. 7-12. (In Russ.)

10. Evrard D., Laforest V., Villot J., Gaucher R. Best Available Technique Assessment Methods: A Literature Review from Sector to Installation Level. Journal of Cleaner Production, 2016, vol. 121, pp. 72-83. doi: 10.1016/j.jclepro.2016.01.096

11. Parry I., Evans D., Oates W. Are Energy Efficiency Standards Justified? Journal of Environmental Economics and Management, 2014, vol. 67, iss. 2, pp. 104-125. doi: 10.1016/j.jeem.2013.11.003

12. Vostrikova S.M. [Modern methods to stimulate enterprises cleaner production technologies]. Aktual'nye problemy gumanitarnykh i estestvennykh nauk = Actual Problems of Humanities and Natural Sciences, 2015, no. 12-6, pp. 29-32. (In Russ.)

13. Klochkov V.V., Ratner S.V. Upravlenie razvitiem 'zelenykh' tekhnologii: ekonomicheskie aspekty [Management of green technology development: economic aspects]. Moscow, IPM RAS Publ., 2013, 291 p.

14. Hegger D.L.T., Van Vliet J., Van Vliet B.J.M. Niche Management and Its Contribution to Regime Change: The Case of Innovation in Sanitation. Technology Analysis \& Strategic Management, 2007, vol. 19, iss. 6, pp. 729-746. doi: 10.1080/09537320701711215

15. Hyysalo S., Juntunen J.K., Freeman S. User Innovation in Sustainable Home Energy Technologies. Energy Policy, 2013, vol. 55, pp. 490-500. doi: https://doi.org/10.1016/j.enpol.2012.12.038

16. Ornetzeder M., Rohracher H. User-led Innovations and Participation Processes: Lessons from Sustainable Energy Technologies. Energy Policy, 2006, vol. 34, iss. 2, pp. 138-150. doi: https://doi.org/10.1016/j.enpol.2004.08.037

17. Brennan T.J., Palmer K.L. Energy Efficiency Resource Standards: Economic and Policy. Utilities Policy, 2013, vol. 25, pp. 58-68. doi: 10.1016/j.jup.2013.02.001

18. Nawrocka D., Parker Th. Finding the Connection: Environmental Management Systems and Environmental Performance. Journal of Cleaner Production, 2009, vol. 17, iss. 6, pp. 601-607. doi: 10.1016/j.jclepro.2008.10.003

19. Khrustalev E.Yu., Ratner P.D. [Eco-Innovation in the electric power industry: Assessing the comparative effectiveness]. Innovatsii = Innovations, 2015, no. 9, pp. 8-14. (In Russ.)

20. Khrustalev E.Yu., Ratner P.D. [Selection of the optimal strategy for the transition of the regional energy system to low-carbon technologies]. Audit i finansovyi analiz = Audit and Financial Analysis, 2015, no. 5, pp. 395-400. (In Russ.)

21. Castelli L., Pesenti R., Ukovich W. DEA-like Models for the Efficiency Evaluation of Hierarchically Structured Units. European Journal of Operational Research, 2004, vol. 154, iss. 2, pp. 465-476. doi: 10.1016/j.jclepro.2008.10.003

22. Petrushchenko V.V. [Heterogeneity accounting in DEA]. Problemy upravleniya = Control Sciences, 2013, no. 5, pp. 2-11. (In Russ.)

\section{Conflict-of-interest notification}

We, the authors of this article, bindingly and explicitly declare of the partial and total lack of actual or potential conflict of interest with any other third party whatsoever, which may arise as a result of the publication of this article. This statement relates to the study, data collection and interpretation, writing and preparation of the article, and the decision to submit the manuscript for publication. 